\title{
Community Empowerment towards Healthy Living through The Implementation of Healthy Living Community Movements (GERMAS)
}

\section{Fazidah A Siregar *, Asfriyati, Lita Sri Andayani}

Faculty of Public Health, Universitas Sumatera Utara, Medan, 20155, North Sumatera, Indonesia

\begin{abstract}
Indonesia is currently facing a triple burden of disease where the incidence of non-communicable diseases is increasing. The condition is related to lifestyle include lack of physical activity, an unhealthy and unbalanced diet, and unhealthy lifestyle as smoking and alcohol consumption. To educate the community to implement healthy living, GERMAS is being promoted, emphasizing promotive and preventive efforts. The purpose of these activities was to educate and mobilize the community to implement healthy living by implementing GERMAS that focuses on physical activities, consuming vegetables and fruit, and checking health regularly. From the health status monitoring, $15.6 \%$ of participants were in the systolic prehypertension stage, and $34.4 \%$ were in the systolic hypertension stage, $19.0 \%$ with high cholesterol levels, $43.8 \%$ with high uric acid levels and $21.9 \%$ with high blood sugar levels. This activity was continued by giving education about balanced and healthy food, routine physical activities during three months and the use of their yards for planting vegetables and fruit and motivating the communities for consuming the healthy food daily. After three months, the health condition improved in which the number of participants with systolic hypertension and high blood sugar levels decreased to $30 \%$ and $12.5 \%$, respectively. It was concluded that the implementation of healthy life society movement daily could reduce the biological risk factors leading to the reduction of non-communicable disease incidence.
\end{abstract}

Keywords: Community empowerment, Healthy living, Germas

Abstrak. Indonesia saat ini menghadapi beban penyakit tiga kali lipat di mana insiden penyakit tidak menular meningkat. Penyakit ini terkait dengan gaya hidup termasuk kurangnya aktivitas fisik, diet yang tidak sehat dan tidak seimbang, dan gaya hidup yang tidak sehat seperti merokok dan konsumsi alkohol. Dalam upaya untuk mendidik masyarakat untuk menerapkan hidup sehat, GERMAS sedang dipromosikan dengan

*Corresponding author at: Faculty of Public Health, Universitas Sumatera Utara, Medan, North Sumatera, Indonesia E-mail address: 
penekanan pada upaya promotif dan preventif. Tujuan dari kegiatan ini dilakukan untuk mendidik dan memobilisasi masyarakat untuk menerapkan hidup sehat dengan menerapkan GERMAS yang berfokus pada kegiatan fisik, mengkonsumsi sayuran dan buah-buahan, serta memeriksa kesehatan secara teratur. Dari pemantauan status kesehatan diperoleh, 15,6\% dari peserta berada dalam tahap prehipertensi sistolik dan 34,4\% berada pada tahap hipertensi sistolik, 19,0\% dengan kadar kolesterol tinggi, 43,8\% dengan kadar asam urat tinggi dan 21,9\% dengan kadar gula darah tinggi. Kegiatan ini dilanjutkan dengan memberikan edukasi tentang makanan sehat dan seimbang, serta melakukan aktivitas fisik selama tiga bulan. Kegiatan lain adalah menggunakan pekarangan untuk menanam sayuran dan buah-buahan dan memotivasi masyarakat untuk mengkonsumsinya setiap hari. Setelah tiga bulan, pemantauan status kesehatan telah dilakukan lagi dan hasilnya menunjukkan bahwa proporsi yang mengalami hipertensi sistolik turun menjadi $30 \%$ serta yang memiliki kadar gula darah yang tinggi menurun menjadi 12,5\%. Disimpulkan bahwa pelaksanaan gerakan hidup sehat masyarakat setiap hari dapat mengurangi faktor risiko biologis dan selanjutnya mengurangi kejadian penyakit tidak menular.

Kata Kunci: Pemberdayaan masyarakat, Hidup sehat, Germas Received July 282020 | Revised September 22 2020| Accepted November 272020

\section{Introduction}

Indonesia is currently facing a triple burden of disease. In addition to infectious diseases that are still high, non-communicable conditions are also high and re-emergence of infectious diseases that have been overcome (Re-emerging disease). Non-communicable diseases are global health problems that need more attention. It is due to the increasing prevalence in line with lifestyle changes. Statistical data shows that $23.3 \%$ of Indonesia's population aged 18 years and over are suffered from non-communicable diseases in 2014 [10].

The risk factors of the non-communicable disease are related to communities' lifestyle, including lack of physical activity, unhealthy and unbalanced diet, obesity, smoking, and alcohol consumption [4]. For an effective non-communicable disease control program, the management should focus on risk factors and implement a comprehensive and integrated manner including health policy, environment, community behaviour and health service dimensions, community empowerment and health sector and program supports [5].

The healthy living community movement (GERMAS) is a national program initiated by the government that focuses on promotive and preventive efforts with communities. The 
program's implementation is conducted by empowering the community with activities, including physical activity and healthy living behaviour, such as providing healthy food and consuming fruits and vegetables daily [6].

In Deli Serdang Regency, the non-communicable disease is one of the common disorders treated at Lubuk Pakam District Hospital [1]. For example, in Klumpang Kebun Village, Hamparan Perak Subdistrict, the proportion of participants with metabolic syndrome were relatively high: $21.9 \%$ high glucose levels and $19.0 \%$ with high cholesterol. The elevation number of diseases needs more attention. This metabolic syndrome is related to lifestyle, including unhealthy eating patterns and lack of physical activity as a risk factor underlying non-communicable diseases. It is necessary to minimize non-communicable disease incidence to educate and mobilize the community to implement healthy living community movement. This activity aimed to educate and mobilize the community to apply a healthy lifestyle through physical activity, consuming vegetables and fruits, and regular health examination.

\section{Method}

There were some methods used in conducting this community service. The first health education was given for communities about the non-communicable disease. Then, health examination included measuring high blood pressure, blood sugar, cholesterol, and uric acid level. Also, assistance was undertaken through exercise activities and education on healthy living. Finally, training was conducted to utilize home yards to grow vegetable and fruit plants and mobilize the community to consume fruits and vegetables daily.

\section{Result and Discussion}

Community service activities were carried out in Klumpang Kebun Village at Hamparan Perak District, Deli Serdang Regency. Klumpang Kebun Village has 12973 people which consists of 6534 men and 6439 women. The majority of 3817 households in Klumpang Kebun Village are Javanese, which works as farm labourers for their living. The targets of these activities were the village community.

Initially, these activities began by educating the community about the non-communicable disease and prevention effort. Then, health status examination was conducted on participants of the community services. It was obtained that $15.6 \%$ of participants were in the systolic prehypertension stage and $34.4 \%$ in systolic hypertension, $19.0 \%$ with high cholesterol levels, $43.8 \%$ with high uric acid and $21.9 \%$ with high blood sugar levels. 
Based on systolic blood pressure examination, it was found that 11 people $(34.4 \%)$ had systolic hypertension, while five people (15.6\%) were in the prehypertensive stage. Moreover, from the diastolic blood pressure analysis, as many as eight people $(25.0 \%)$ were in the prehypertension stage, only one person (3.1\%) had experienced hypertension. Most participants (78.1\%) had normal blood sugar levels in terms of blood sugar levels, while seven people (21.9\%) had high blood sugar levels. Finally, from the cholesterol examination results, six people $(19.0 \%)$ had high cholesterol levels, and $81 \%$ of the older people had normal cholesterol levels. Likewise, 14 (43.8\%) of the elders had high uric acid levels.

Hypertension is recognized as a "silent killer" because it is a disease without typical signs and symptoms. In contrast, the community considers hypertension a regular thing and only appears when it is severe and causes dangerous complications such as stroke [8]. Moreover, hypertension increases the risk of heart disease, stroke, kidney disorders and retinopathy [9].

There is much research that shows the relationship between cholesterol levels and blood pressure. In other words, high blood cholesterol levels are found in many people with hypertension. The increase of cholesterol levels is related to fat deposits that can reduce blood vessels' elasticity in regulating blood pressure causing high blood pressure. Many epidemiological studies have shown an increase in the risk of Congestive Heart Disease (CHD) and hypertension related to elevated serum total cholesterol [2]. Many epidemiologic studies show a progressive increase in the risk of CHD and hypertension in serum total cholesterol that exceeds $193.2 \mathrm{mg} / \mathrm{dl}$ [3].

Many factors cause hypercholesterolemia, including genetic factors and secondary factors due to other diseases such as diabetes mellitus, nephrotic syndrome and saturated fat dietary habits, obesity, lack of exercise, smoking and age. With the increase in age, older people have higher cholesterol levels and lack of physical activity. The previous study reported that regular physical activity could reduce LDL cholesterol and triglyceride levels [7].

Health education about healthy food and physical activity was given three times at intervals of 10 days. This activity was followed by mentoring health living behaviour, physical activity and healthy food. Another action was utilizing yards to plant fruits and vegetables and mobilize the community to consume fruits and vegetables daily. At the end of this activity, health monitoring was performed again to know the outcome of this activity. The results showed that the proportion of high blood pressure and high blood 
sugar decreased to $30 \%$ and $12.5 \%$, respectively. Additionally, the communities used their yards for fruit and vegetable plants, and they also had an excellent habit of consuming fruits and vegetables daily. After finishing this activity, it is expected that the communities can maintain a positive routine daily to prevent non-communicable disease.

\section{Conclusion}

In the first examination, we found some of the participants had high blood pressure and blood sugar. The condition could have a risk factor for non-communicable diseases such as hypertension and diabetes mellitus. After three months of implement healthy living community movements, we found the tendency of lower blood pressure and blood sugar level in the communities. Therefore, it was concluded that healthy alive community movement could reduce biologic disorder risk and non-communicable disease risk. Hence, we suggested that they apply healthy living community movement (Germas) daily to prevent non-communicable diseases.

\section{Acknowledgements}

We want to thank the Rector and Community Service Institute of Universitas Sumatera Utara for approval and financial support. Also, for all those who assist in this activity.

\section{References}

[1] Health Department, Deli Serdang Regency. Data of non-communicable disease. 2014.

[2] S. Fujikawa, R. Iguchi, T. Noguchi, and M. Sasaki, "Cholesterol crystal embolization following urinary diversion: a case report". Hinyokika Kiyo. Acta Urologica Japonica, vol. 61, no. 3, pp. 99-102, 2015.

[3] P. Libby, The pathogenesis, prevention, and treatment of atherosclerosis. In: A.S. Fauci, E. Braunwald, D.L. Kasper, S.L. Hausen, D.L. Longo, J.L. Jameson, et al., editors, Harrison's principles of internal medicine. 17th ed. New York "Mc Graw Hill, pp.1501-1503, 2008.

[4] Ministry of Health, Republic of Indonesia. Infodatin Hipertension. Jakarta. 2014.

[5] Ministry of Health, Republic of Indonesia. Operational Plan for Health Promotion in the Control of Non-Communicable Diseases. 2010.

[6] Ministry of Health, Republic of Indonesia. Healthy living community health movement towards Healthy for Indonesian. 2016.

[7] J. Skoumas, C. Pitsavos, D.B. Panagiotakos, C. Chrysohoou, A. Zeimbekis, I. Papaioannou, and C. Stefanadis, "Physical activity, high-density lipoprotein cholesterol and other lipids levels, in men and women from the ATTICA study." Lipids in health and disease, vol. 2, no. 1, p. 3, 2003.

[8] J. Tarsia, T.R. Chang, A. Aysenne, A.K. Boehme, A.E. Sartor, K.C. Albright, S. Martin-Schild, "Elevated Plasma Factor VIII in Patients with Ischemic Stroke: Does it have any Association with Hypertensive Heart Disease?" Journal of Neurological Disorders \& Stroke, vol. 1, no. 3, pp. 1027-1027, 2013. 
[9] Z. Tian, Y.T. Liu, Q. Fang, C. Ni, T.B. Chen, L.G. Fang, X.F. Zeng, "Hemodynamic parameters obtained by transthoracic echocardiography and right heart catheterization: a comparative study in patients with pulmonary hypertension." Chinese Medical Journal, vol. 124, no. 12, pp. 1796-1801, 2011.

[10] World Health Organization. World Health Statistic. Geneva. 2015. 